\title{
Thin-layer chromatography of L-carnitine in micellar and cyclodextrin mobile phases
}

(C) Anna O. Ustyugova, ${ }^{1}$ Elena G. Sumina, ${ }^{1}{ }^{+}$Varsenia Z. Uglanova ${ }^{2}$ and Olga N. Novozhilova ${ }^{3}$

${ }^{1}$ Department of Analytical Chemistry and Chemical Ecology; ${ }^{2}$ Department of Petrochemistry and Technological Safety. N.G. Chernyshevsky Saratov National Research State University. Astrakhanskaya St., 83. Saratov, 410012. Russia. Phone: ${ }^{1)}+7$ (964) 879-65-27; ${ }^{2)}+7$ (919) 833-02-05.

E-mail:: ${ }^{1)}$ SuminaEG@yandex.ru, ${ }^{2)}$ UglanovaVZ@mail.ru

${ }^{3}$ Saratov State Medical University named after V.I. Razumovsky under Ministry of Health of the Russian Federation. Bolshaya Kazachia St., 112. Saratov, 410012. Russia. Phone:+7 (908) 555-56-34.E-mail: Sorokina-O-N@yandex.ru

\section{*Supervising author; ${ }^{+}$Corresponding author}

Keywords: thin-layer chromatography, L-carnitine, surfactants, cyclodextrins.

\begin{abstract}
L-carnitine (lat. Levocarnitinum, eng. Levocarnitine) is a natural substance akin to B vitamins. Normalizing metabolic processes in the human body and having a wide range of therapeutic actions, L-carnitine is widely used in cardiology, neurology, gastroenterology, and sports medicine. Currently, modern analytical techniques, such as mass spectrometry, high performance liquid chromatography, radiation methods, etc., are used to analyze Lcarnitine. Most of them are rather expensive and time consuming. Thin-layer chromatography (TLC), which is notable for its simplicity, feasibility of analysis, separation efficiency and low cost, has received much less use. In this regard, the purpose of this work was to reveal the analytical capabilities of water-organic, micellar and cyclodextrin mobile phases for the analysis of L-carnitine by means of TLC.

Initial L-carnitine solutions with a concentration of $20 \mathrm{mg} / \mathrm{ml}$ were prepared by diluting solutions for injections. Their chromatography was carried out by ascending thin-layer chromatography on plates of various polarities (Sorbfil, Plasmachrom, and RP-18) with a fixed sorbent layer. Aqueous solutions of surfactants (cetyltrimethylammonium bromide, cetylpyridinium chloride, sodium dodecyl sulfate, Triton X-100), of cyclodextrins ( $\beta$-cyclodextrin, 2-hydroxypropyl- $\beta$-cyclodextrin), hydroxypropyl- $\gamma$-cyclodextrin) were used as mobile phases. The zone of the main substance (L-carnitine) was identified by treating the plate with a mixture of freshly prepared $0.1 \mathrm{~N}$ solution of potassium permanganate and $2.0 \mathrm{~N}$ acetic acid (the zone was colored in a light yellow color).

Main features of the chromatographic behavior of L-carnitine were revealed. Based on the calculation of the number of theoretical plates and the height equivalent to one theoretical plate, it was shown that aqueous micellar and cyclodextrin mobile phases allow one to improve the chromatographic process efficiency and the shape of the chromatographic zones of L-carnitine as compared to water-organic eluents; cheaper Sorbfil plates (Russia) can be used for practical purposes.

Optimal chromatographic systems and conditions for their use in the thin-layer chromatography of pharmaceuticals and food products have been selected and substantiated.
\end{abstract}

\section{References}

[1] D.I. Medvedev, O.B. Savrova, I.Z. Eremina. Carnitine and its efficiency after protein energy malnutrition. Morphological Newsletteu. 2005. No.3-4. P.69-71. (russian)

[2] S.V. Shterman. L-carnitine: bioenergy in each cage. Moscow. 2011. 125p. (russian)

[3] L.A. Balykova, S.A. Ivyanskiy, Yu.O. Soldatov, A.A. Shirokova, N.V. Shchekina, A.N. Urzyaeva. Lcarnitine as a way to increase adaptation and correct health disorders in young athletes during intense exercising. Practical Medicine. 2014. No.9(85). P.140-146. (russian)

[4] V.M. Podobed. The effectiveness of applying carnitine-based drugs in pediatrics (literature review). Paediatrics. Eastern Europe. 2015. No.2(10). P.92-101. (russian)

[5] E.V. Efimova, T.A. Gus'kova, V.M. Kopelevich, V.I. Gunar. Acetyl-L-carnitine: Biological properties and clinical application (A review). Pharmaceutical Chemistry Journal. 2002. Vol.36. No.3. P.111-115. (russian) 
[6] M. Dambrova, M. Makrecka, R. Vilskersts, J. Kuka, E. Liepinsh. Carnitine as a Marker of Atherosclerosis and Oher Risks of Cardiovascular Diseases. Kardiologiia. 2014. Vol.54. No.8. P.91-96. (russian)

[7] S.V. Lobzin, V.I. Golovkin, L.O. Popova. Carnitine and its derivatives in cerebrovascular diseases. Russian Family Doctor. 2013. Vol.17. No.1. P.40-44. (russian)

[8] S.I. Gavrilova, Ia.B. Kalyn, I.V. Kolykhalov, I.F. Roshchina, N.D. Selezneva. Acetyl-L-carnitine (carnicetine) in the treatment of early stages of Alzheimer's disease and vascular dementia. Neuroscience and Behavioral Physiology. 2011. Vol.111. No.9. P.16-22. (russian)

[9] L.V. Shalkevich, A.V. Malash. Metabolic therapy of diseases of the nervous system in children by carnitine-based medicinal products. Meditsinskie Novosti. 2016. No.4. P.28-32. (russian)

[10] O.V. Guzeva. Indicators of the maintenance of carnitines and amino acids in blood at children with epilepsy. Pediatric Neurosurgery and Neurology. 2013. No.2(36). P.30-41. (russian)

[11] T.S. Gorban, M.V. Degtyareva, O.A. Babak, Yu.N. Vorontsova, E.Yu. Zakharova, G.V. Baydakova, N.N. Volodin. Dynamics of carnitine concentrations in blood serum in infants with very low birth weight. Clinical Practice in Pediatrics. 2011. Vol.6. No.4. P.28-32. (russian)

[12] The guide to methods of quality control and safety of dietary supplements to food. Moscow. Federal center of Gossanepidnadzor of the Russian Ministry of Health. 2004. 240p. (russian)

[13] Qing-Ri Cao, Shan Ren, Mi-Jin Park, Yun-Jaie Choi, Beom-Jin Lee. Determination of Highly Soluble L-Carnitine in Biological Samples by Reverse Phases High Performance Liquid Chromatography with Fluorescent Derivatization. Arch. Pharm. Res. 2007. Vol.30. No.8. P.1041-1046.

[14] Réjane Morand, Massimiliano Donzelli, Manuel Haschke, Stephan Krähenbühl Quantification of plasma carnitine and acylcarnitines by high-performance liquid chromatography-tandem mass spectrometry using online solid-phase extraction. Clin Chem. 2008. Vol.54(9). No.4. P.1451-1462.

[15] Frédéric M. Vaz, Bela Melegh, Judit Bene, Dean Cuebas, Douglas A. Gage, Albert Bootsma, Peter Vreken, Albert H. van Gennip, Loran L. Bieber, Ronald J.A. Wanders Analysis of carnitine biosynthesis metabolites in urine by HPLC-electrospray tandem mass spectrometry. Clin. Chem. 2002. No.48. P.826-834.

[16] P.N. Sorokoumov, E.I. Savelieva, G.V. Karakashev, V.A. Kopeikin, A.S. Radilov. Determination of meldonium, $\gamma$-butyrobetaine, and $\gamma$ determination of meldonium, carnitine in blood plasma by highperformance liquid chromatography with mass-selective detection. Drug Development and Registration. 2016. No.1(14). P.176-183. (russian)

[17] K.G. Seline \& H. Johein. The determination of L-carnitine in several food sample. Food Chemistry. 2007. No.105. P.793-804.

[18] J. Demarquoy, B. Georges, C. Rigault, M.Ch. Rouer, A. Clairet, M. Soty et al. Radioisotopic determination of L-carnitine content in foods commonly eaten in Western countries. Food Chemistry. 2004. No.86. P.137142.

[19] Manjón, A., Obón, J. M., \& Iborra, J. L. Determination of L-carnitine by flow injection analysis with NADH fluorescence detection. Analytical Biochemistry. 2000. No.281. P.176-181.

[20] L.A. Kartsova, E.G. Strel'Nikova. Determination of endo- and exogenous corticosteroids by cyclodextrin-modified micellar electrokinetic chromatography with the use of on-line preconcentration. J. of Anal. Chem. 2007. Vol.62. No.9. P.965-968. (russian)

[21] S.B. Savvin, R.K. Chernova, S.N. Shtykov. Surfactants (Analytical reagents). Moscow: Science. 1991. 251p. (russian)

[22] A.A. Shteinman. Cyclodextrins. J. All-Russian Chem. Soc. 1985. Vol.30. No.5. P.514-518. (russian)

[23] E.G. Sumina, S.N. Shtykov, N.V. Tyurina. Surfactants in Thin-Layer Chromatography. J. of Anal. Chem. 2003. Vol.58. No.8. P.720-730. (russian)

[24] E.G. Sumina. Organized Nanosistems in thin-layer chromatography. Sorb. \& chromatogr. processes. 2010. Vol.10. No.1. P.150-160. (russian)

[25] E.G. Sumina, S.N. Shtykov, O.N. Sorokina, A.V. Petrakova, V.Z. Uglanova. Thin-layer chromatography of flavonoid s on silica gel in modified micellar mobile phases based on sodium dodecylsulfate. Sorb. \& Chromatogr. Processes. 2014. Vol.14. No.1. P.52-64. (russian)

[26] S.B. Vorozheikin, E.S. Bashko, S.N. Shtykov. Thin-layer chromatography of amino acids in micelle mobile phases on silicagel. Sorb. \& Chromatogr. Processes. 2011. Vol.11. No.6. P.840-847. (russian)

[27] A. Mohammad, Y.H. Sirwal. A New Anionic Micellar Mobile Phase System for the Normal-Phase Thin-Layer Chromatography of Amino Compounds: Simultaneous Separation of Aminophenol Isomers. J. of Analyt. Chem. 2003. Vol.58. No.8. P.731-739. (russian)

[28] L.A. Kartsova, E.V. Obedkova, I.D. Protasova. Enantioseparation of non-steroidal anti-inflammatory drugs and $\beta$-blockers by high-performance thin-layer chromatography. Sorb. \& Chromatogr. Processes. 2013. Vol.13. No.3. P.257-265. (russian) 
[29] E.G. Sumina, V.Z. Uglanova, O.N. Sorokina, and A.O. Ustyugova. Comparative analysis of meldonium by TLC in water-organic, aqueous micellar and cyclodextrin mobile phases. Butlerov Communications. 2018. Vol.56. No.11. P.38-46. DOI: 10.37952/ROI-jbc-01/18-56-11-38

[30] E.G. Sumina, V.Z. Uglanova, T.E. Sorokina, and O.N. Sorokina. Thin-layer chromatography of some benzene derivatives in aqueous and modified by cyclodextrins mobile phases. Butlerov Communications. 2016. Vol.45. No.3. P.51-59. DOI: 10.37952/ROI-jbc-01/16-45-3-51

[31] Yu.V. Mudredtsova. Development of techniques of the analysis and studying of stability is well-cared an alfostserat and a meldonium in solution for injections. Dis. on competition of an academic degree of the candidate of pharmaceutical sciences. 2014. 166p. (russian)

[32] V.D. Shatz, O.V. Sakhartova. High-performance liquid chromatography. Riga. 1988. 160p.

[33] S.N. Shtykov, E.G. Sumina, V.Z. Uglanova, O.N. Sorokina. Thin-layer chromatography of some amino acids on silica in aqueous-organic and modified micellar mobile phases. J. of Anal. Chem. 2017. Vol.72. No.8. P.742-750. (russian)

[34] E.G. Sumina, V.Z. Uglanova, O.N. Sorokina, and A.I. Danchuk. Comparative analysis of glycyrrhizic acid by TLC and HPLC modified with surfactants and organic solvents. Butlerov Communications. 2015. Vol.44. No.12. P.94-100. DOI: 10.37952/ROI-jbc-01/15-44-12-94

[35] E.G. Sumina, V.Z. Uglanova, O.N. Sorokina, D.O. Afonina. Analysis of the purity of preparations of corticosteroid hormones by thin-layer chromatography in mobile phases based on cyclodextrins and surfactants. Izv. Saratov University. New Series. Chemistry. Biology. Ecology. 2011. Vol.11. No.2. P.48-53. (russian)

[36] E.G. Sumina, S.N. Shtykov, V.Z. Uglanova, O.N. Sorokina. Liquid chromatography of some steroid hormones in aqueous-organic, micellar, and cyclodextrin mobile phases. J. Anal. Chem. 2014. Vol.69. No.10. P.1105-1113. (russian)

[37] A.A. Abramzon. Surface-active substances: properties and applications. Leningrad: Chemistry. 1981. $304 p$.

[38] E.G. Sumina, V.Z. Uglanova, and O.N. Sorokina. Use of cyclodextrin mobile phases in chin-layer chromatography of fluoresceins. Butlerov Communications. 2017. Vol.50. No.4. P.123-132. DOI: 10.37952/ROI-jbc-01/17-50-4-123

[39] E.G. Sumina, V.Z. Atayan, S.N. Shtykov. Application of cyclodextrins mobile phases in the thin-layer chromatography of the xantens and chinolins organic reagents of ranks. Sorb. \& Chromatogr. Processes. 2008. Vol.8. No.1. P.83-93. (russian)

[40] V.Z. Atayan, E.G. Sumina, S.N. Shtykov. Thin-layer chromatography of azo compounds in cyclodextrin-modified mobile phases. Sorb. \& Chromatogr. Processes. 2003. Vol.3. No.4. P.392-398. (russian)

[41] F. Geiss. Fundamentals of Thin Layer Chromatography (Planar Chromatography). Heidelberg-BaselNew York: Dr Alfred Huethig Verlag. 1987. (russian) 